\title{
Health education: a booklet for colostomized people in use of the plug
}

\author{
Cartilha para pessoas com colostomia em uso do oclusor: educação em saúde \\ Cartilla para personas con colostomía en uso del obturador: educación en salud
}

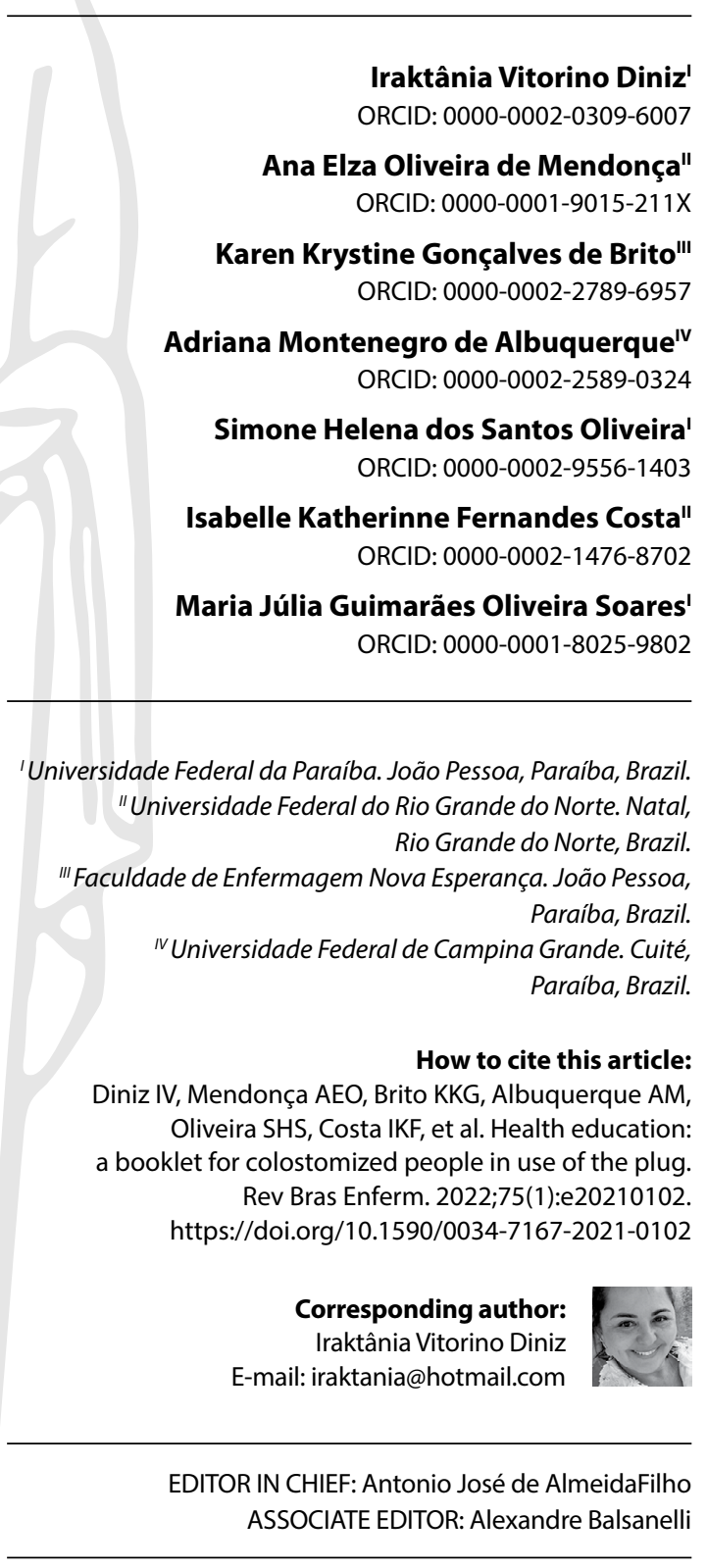

Submission: $07-22-2020$

Approval: 03-24-2021

\begin{abstract}
Objective: To develop and validate a booklet on the use of the colostomy plug as a technological support for educational intervention. Methods: Methodological study focusing on the production of soft and hard technologies for colostomized people using a plug, developed in three stages: literature review; validation with 13 experts; and with seven colostomized persons. Results: The content for the booklet was selected based on the analysis of the articles identified in Step 1. In Step 2, regarding the content, the number of pages and appearance obtained a Content Validity Index of 0.85 and 1.00 respectively. In Step 3, the minimum Content Validity Index was 0.71 in two items related to organization and 0.86 for the writing style. The other items obtained a Content Validity Index of 1.0. Conclusion: The booklet was validated among experts and colostomized persons, and the final version, containing 50 pages, was offered to health professionals and colostomized people in use of a plug.

Descriptors: Health Education; Colostomy; Rehabilitation; Persons; Nursing.
\end{abstract}

\section{RESUMO}

Objetivo: Construir e validar cartilha sobre o uso do oclusor da colostomia como suporte tecnológico para intervenção educativa. Métodos: Estudo metodológico com foco na produção de tecnologia leve-dura para pessoas colostomizadas em uso de oclusor, desenvolvido em três etapas: revisão da literatura; validação com 13 experts; e com 7 pessoas colostomizadas. Resultados: $O$ conteúdo que compôs a cartilha foi selecionado com base na análise dos artigos identificados na Etapa 1. Na Etapa 2, quanto ao conteúdo, o número de páginas e a aparência obtiveram Índice de Validade de Conteúdo 0,85 e 1,00 respectivamente. Na Etapa 3, o Índice de Validade de Conteúdo mínimo foi de 0,71 em dois itens referentes à organização e 0,86 no estilo da escrita. Os demais itens obtiveram Índice de Validade de Conteúdo 1,0. Conclusão: Validou-se a cartilha com experts e pessoas colostomizadas, e a versão final, contendo 50 páginas, foi ofertada aos profissionais da área de saúde e pessoas colostomizadas em uso do oclusor.

Descritores: Educação em Saúde; Colostomia; Reabilitação; Pessoas; Enfermagem.

\section{RESUMEN}

Objetivo: Construir y validar cartilla de uso del obturador de colostomía como suporte tecnológico para intervención educativa. Métodos: Estudio metodológico basado en producción de tecnología leve-dura para personas colostomizadas en uso de obturador, desarrollado en tres etapas: revisión de la literatura; validación con 13 expertos; y 7 personas colostomizadas. Resultados: Contenido que compuso la cartilla fue seleccionado basado en análisis de artículos identificados en la Etapa 1. En la Etapa 2, cuanto al contenido, el número de páginas y la apariencia obtuvieron Índice de Validez de Contenido 0,85 y 1,00 respectivamente. En la Etapa 3, el Índice de Validez de Contenido mínimo fue de 0,71 en dos ítems referentes a la organización y 0,86 en el estilo de la escrita. Los demás ítems obtuvieron Índice de Validez de Contenido 1,0. Conclusión: Validó la cartilla con expertos y personas colostomizadas, y la versión final, conteniendo 50 páginas, ofertada a los profesionales de la área de salud y personas colostomizadas en uso del obturador. Descriptores: Educación en Salud; Colostomía; Rehabilitación; Personas; Enfermería. 


\section{INTRODUCTION}

Ostomy is a surgical procedure used to communicate a hollow viscera to the external environment, be it temporarily or permanently ${ }^{(1)}$. The most frequent stomas are the ones for gastrointestinal tract excretion, called colostomies and ileostomies, which allow feces and flatus to exit; and occur for various reasons such as trauma, congenital malformations, infectious intestinal diseases, and colon and rectal cancer ${ }^{(2-3)}$.

Undergoing a colostomy procedure results in changes in people's lives due to the need to adapt to the new condition of eliminating excreta. Anxiety arises from the moment of the discovery of the disease and the need of undergoing surgery, at which time you must choose between the procedure or giving in to the disease that will result in death ${ }^{(4)}$.

Faced with certain situations, the individual begins to face difficulties in understanding his own existential condition, revealing feelings of denial, non-conformity, and embarrassment. Aesthetic changes in people with colostomy and changes in activities are elements that influence the acceptance of self-image and social isolation and lead to prejudiced attitudes. These individuals suffer physical, psychological, social, and spiritual changes, requiring nursing care to guide and educate them on their newly arising needs, the outcomes of falling ill(5-6).

The adaptation challenges of people with colostomy are related to changes in eating habits, clothing, physical, leisure, and sexual activities, and returning to work ${ }^{(7)}$. As of the preoperative period, recommendations are made focused on educating people undergoing the surgical procedure to implement the intestinal stoma and family members about the ostomy, demarcation of the stoma, psychological preparation, and exploration of the possible impact of the ostomy regarding sexuality ${ }^{(8)}$.

In the perspective of minimizing suffering and improving the adaptation of colostomized people, continence systems emerged, with an emphasis on plugs, which provide control of intestinal excretion and improve the lives of these people. A pilot study with 30 colostomized persons demonstrated that the use of this system promotes safety and efficacy in the control of excretion and intestinal gases as an innovation replacing colostomy bags ${ }^{(9)}$.

The colostomy plug aims to occlude its distal extremity by controlling the incontinence of feces and gases, as well as noise and odor. It is a disposable, flexible cylindrical plug, composed of polyurethane foam surrounded by a pre-lubricated water-soluble film, with an integrated activated carbon filter to inhibit odors; its indication depends on the medical evaluation and the clinical conditions of the patient ${ }^{(10-11)}$.

Studies describe the benefits of the use of the plug by itself, without colostomy irrigation ${ }^{(12-14)}$. As for its disadvantages, another more recent study mentions the cost, use limitations, need for monitoring and training, leakage risk based on pressure, and intestinal peristalsis ${ }^{(15)}$.

A randomized clinical study with 60 ostomized persons demonstrates that ostomy training plays an important role in helping their adaptation, living with it, and improving their psychological well-being and quality of life ${ }^{(16)}$. The nurse can and should promote strategies that favor the adaptation and the quality of life of ostomized patients. It is assumed that training, guidance, the use of education, and the use of educational tools, can make important contributions in this direction.

Thus, the introduction of technological tools for teaching is essential. In nursing, the teacher-student relationship goes beyond the academic area, as there is also the nurse-patient relationship, as well as the health work process ${ }^{(17)}$.

In addition, research emerges as a fundamental strategy for the production of technology that, in addition to acting as a health information/education tool, strengthens nursing care. This is considered a transformation tool that enables education, investigation, and reflection of a phenomenon that involves major change in the life of someone and/or a population ${ }^{(18)}$.

It is important to highlight that the narrative review of the literature and the empirical basis of the stomatherapist researcher who works in the area favored the development of the booklet. It is known that the benefits of using technologies in nursing teaching and learning environments promote transformation strategies and challenges that characterize the current reality ${ }^{(17)}$.

When experiencing caring of people with intestinal stoma, specifically in the process of teaching them how to use the plug, the need for an informative/educational material was identified to assist the monitoring of ostomized patients registered in the training program.

From this concern, the interest emerged to develop a booklet with guidelines and systematic monitoring to support the use of this technological device - the colostomy plug - in an individualized way and, thus, provide educational and motivational support.

\section{OBJECTIVE}

To develop and validate a booklet on the use of the colostomy plug as a technological support for educational intervention.

\section{METHODS}

\section{Ethical aspects}

The research was approved by the Research Ethics Committee of the Universidade Federal da Paraíba [Federal University of Paraíba]. After clearing participants' doubts, participation in the study was made official by signing the Informed Consent Form (ICF). It is noteworthy that the ethical and legal criteria that regulate the use of texts and images were respected, not violating any copyrights.

\section{Study design, location, and period}

Methodological study for the development of a soft-hard technology in the format of a booklet, aimed at the colostomized person using a plug, following the guidelines of the Revised Standards for Quality Improvement Reporting Excellence (SQUIRE 2.0). The booklet was constructed during the doctoral research entitled "Adaptação e qualidade de vida de pessoas estomizadas" [Adaptation and quality of life of people with stomas] and idealized based on the researcher's experience in assisting this population - in daily practice, the need for a technology that guided the use of the colostomy plug and assist in the process of training and monitoring the colostomized person. 
The booklet was produced between the months of November 2018 and February 2019, at a reference center for the care of ostomized people. The data revision stage counted on the collaboration of 13 experts and suggestions from seven colostomized patients after using and filling out the booklet.

\section{Study protocol}

Stage 1 - Narrative review of the literature to support textual guidelines of the booklet; selection of information from illustrative images (photos, products, and figures), creation of characters and their embodiment into drawings; refining the information extracted from the selected material based on the researcher's theoreticalpractical expertise on the topic; ensuring the language used was adequate in order to make the instrument accessible to people with different levels of education; and content review, photos, drawings, and layout. As a result, we had the first version of the booklet.

The review was carried out in the following bases and libraries: Literatura Latino-Americana e do Caribe em Ciências da Saúde (LILACS) [Latin American and Caribbean Health Sciences Literature], MEDLINE EBSCO host, PubMed Central, Cumulative Index to Nursing and Allied Health Literature (CINAHL), and Web Of Science. Articles were selected that fit the inclusion criteria and answered the guiding question: What scientific production is available on the colostomy plug since its creation?

The following descriptors were used for research: colostomy and plug. Inclusion criteria were: publications that addressed the colostomy plug in the period from 1984 to 2020 (ever since the plug was created). Exclusion criteria: duplicate publication in the databases, theses, and dissertations, and those that did not include the colostomy plug. A total of 38 articles were found, being: 24 articles in PubMed, five articles in LILACS, one in Web of Science (duplicate), none in CINAHL, eight in MEDLINE EBSCO host (five did not address the theme; and three were duplicates), totaling a final sample of 14 articles.

Step 2 - After the construction of the first version, the booklet was subjected to content and appearance evaluation by experts on the subject. The professionals were personally invited and informed about the purpose of the booklet. After accepting the invitation, the first version was delivered, printed on A4 paper, paginated and colored, in the format of a booklet to facilitate handling; or in digital format, sent by e-mail to anyone who previously requested it. The period for analysis was a maximum of 30 days. A semi-structured questionnaire ${ }^{(19)}$ was adapted to the criteria analyzed by the group of evaluators ${ }^{(19)}$ with seven questions related to content and four related to appearance, organized in a Likert scale format with three judgment options:"adequate","partially adequate" and"inappropriate".

The suggestions were analyzed individually and discussed in a team composed of the responsible researcher, the advisor, and the reviewer. They were members of: the Wound Prevention and Treatment Research Group (GEPEFE) and of Chronic Diseases (GPDOC) at the Federal University of Paraíba; the Nursing Graduate Program (PPGENF); and the Center for Studies and Research in Dermatology and Stomatherapy of the Federal University of Rio Grande do Norte (NEPeDE). The suggestions were carefully observed, welcoming those that would contribute to the improvement of the booklet.

Step 3 - The second version of the booklet was evaluated by the colostomized people, who were intentionally selected for training in the use of the plug. Seven colostomized patients participated in this stage to evaluate the booklet and make suggestions regarding the content (text and images), language comprehension (clarity) and space for filling the notes diary. For this stage, an instrument adapted with 13 questions regarding the organization, writing style, appearance, and motivation was used. There were three answer options for each question: positive (yes/easy to comprehend/clear/interesting), impartial (partially/l don't know), and negative (no/difficult to comprehend/confusing/ uninteresting), depending on each type of question ${ }^{(20)}$.

\section{Sample: eligibility criteria for professionals and colosto- mized people}

In Step 2, corresponding to the selection of experts, the snowball technique strategy was used. In this perspective, the search began in the reference service of ostomy patients and with stoma therapists linked to the Brazilian Society of Stomatherapy (SOBEST).

For the selection of professionals, it was taken into account to be a stomatherapy specialist or professor-researcher and to have practical experience in caring for people with stoma. The booklets were handed to 18 health professionals, and 13 provided feedback, specifically: four stomatherapy nurses, seven higher education nurses with a doctorate degree, one general surgeon, and one resident doctor in coloproctology. The average training of professionals was of 15 years.

For Stage 3, seven people with colostomy who attended the service (Reference and Care Center for People with Disabilities) were invited, and the inclusion criteria for participation were: having a permanent colostomy, who had been advised to use the device; age equal to or greater than 18 years; an education level compatible with the required for reading and understanding the material; attendance at the Reference and Care Center for People with Disabilities (CRCPD) during the data collection period; having an availability of 10 to 20 minutes to participate in the reading and guidance on the use of the booklet; and answering the assessment instrument. Excluded, were those with no schooling or who presented difficulties that prevented them from reading, comprehending, and responding to the instrument for training in the use of the colostomy plug.

\section{Analysis of results and statistics}

To measure the level of evaluator agreement, the Content Validity Index (CVI) was adopted, which measures the judges' agreement regarding the representativeness of the items presented within the content being studied, calculated by dividing the number of judges that assessed the item as "adequate"/"partially adequate" by the total number of judges (evaluation per item), resulting in the proportion of judges who judged the item valid. For the validation of the educational booklet by the judges who were part of the study reality, the items and the instrument as a whole should have a CVI greater than or equal to 0.70 . For validating appearance, the experts judged the images as to their disposition, whether they were expressive and relevant to the content, clear, and objective.

For analyzing the items judged by the target audience, data with an agreement level greater than 0.70 in the positive responses were also considered validated, which was calculated through the 
number of people in the target audience who evaluated the item with positive responses, divided by the total number of people in the target audience.

In order to calculate the general CVI of the instrument, the sum of all CVIs calculated separately, per stage, was carried out and divided by the number of items in each stage ${ }^{(21)}$. Expert and target audience suggestions for improving the booklet were analyzed and accepted.

\section{RESULTS}

After reviewing the literature, the initial version of the educational booklet for people using the plug was developed. The contents were described in sequence: Presentation; Definition of intestinal stoma; Some stoma and skin problems; Types of ostomy bags; Ostomy products; Continence systems; How to use the plug; How to change the plug; Common questions; Motivational tips; Important notes; Notes of reminder/doubts; Necessary guidelines; Stages for plug usage; Diary of notes for each stage; You did it; You are not alone; and a list of Contacts.

The first version of the booklet sent to the specialists underwent adjustments recommended in the second stage of the study. These adjustments were related to the: title of the booklet, in the sense of it being more concise; initial presentation, to insert its main objective; inserting an image in the stoma definition and modifications in two drawings, to improve their appearance (changes in the layout of images and colors). The recommended modifications were analyzed and considered pertinent, according to the Content Validation Index described in Table 1.

Moving on to the restructuring of the booklet, its second version was handed to seven colostomized people to assess its use.

Colostomized patients' notes regarding complications made it possible to include specific topics to describe the care to be taken in cases of plug ejection, effluent leakage, plug exchange, the presence of cramps and malaise. The suggested modifications were: placing schedules in the notes diary; the inclusion of a phone book; modifying the text for a better understanding of the definition of prolapsed stoma; include products to prevent and treat complications; provide more stoma adjuvants; and the irrigation kit to get to know the product and have other options to choose from. In the item "Frequently asked questions", insert the question "Can the person with an ileostomy use the plug?"; clarify the use of the plug at night, regarding its permanence, according to the Content Validation Index in Table 2.

Table 1 - Experts' evaluation of the booklet's content and appearance, João Pessoa, Paraíba, Brazil, 2019

\begin{tabular}{|c|c|c|c|c|}
\hline Contents & $\begin{array}{c}\text { Adequate } \\
\text { n (\%) }\end{array}$ & $\begin{array}{c}\text { Partially adequate } \\
\text { n (\%) }\end{array}$ & $\begin{array}{c}\text { Inadequado } \\
\text { n (\%) }\end{array}$ & CVI \\
\hline 1. Well-structured content. & $9(69.2)$ & $4(30.8)$ & $0(0.0)$ & 1.00 \\
\hline 2. The text sequence is logical. & $9(69.2)$ & $4(30.8)$ & $0(0.0)$ & 1.00 \\
\hline 3. The information is presented in a clear and objective way. & $5(38.5)$ & $8(61.5)$ & $0(0.0)$ & 1.00 \\
\hline 4. The wording is accessible to the target audience. & $11(84.6)$ & $2(15.4)$ & $0(0.0)$ & 1.00 \\
\hline 5. The information on the cover, back cover, and presentation are coherent. & $8(61.5)$ & $5(38.5)$ & $0(0.0)$ & 1.00 \\
\hline 6. Adequate title and topics. & $10(76.9)$ & $3(23.1)$ & $0(0.0)$ & 1.00 \\
\hline 7. Adequate number of pages. & $6(46.2)$ & $5(38.5)$ & $2(15.4)$ & 0.85 \\
\hline \multicolumn{5}{|l|}{ Appearance } \\
\hline 1. Is expressive enough. & $10(76.9)$ & $3(23.1)$ & $0(0.0)$ & 1.00 \\
\hline 2. Is pertinent to the content. & $9(69.2)$ & $4(30.8)$ & $0(0.0)$ & 1.00 \\
\hline 3. Is clear and conveys the message. & $9(69.2)$ & $4(30.8)$ & $0(0.0)$ & 1.00 \\
\hline 4. The captions applied to the images are appropriate. & $13(100.0)$ & $0(0.0)$ & $0(0.0)$ & 1.00 \\
\hline General CVI & & & & 0.99 \\
\hline
\end{tabular}

CVI - Content Validity Index.

Table 2 - Colostomized participants' evaluation of the booklet regarding organization, style of writing, appearance, and motivation, João Pessoa, Paraíba, Brazil, 2019

\begin{tabular}{|c|c|c|c|}
\hline Evaluated items & $\begin{array}{c}\text { Positive responses } \\
\text { n (\%) }\end{array}$ & $\begin{array}{c}\text { Impartial responses } \\
n(\%)\end{array}$ & CVI \\
\hline \multicolumn{4}{|l|}{ Organization } \\
\hline Did the cover catch your eye? & $7(100.0)$ & $0(0.0)$ & 1.00 \\
\hline Is the sequence of the content appropriate? & $5(71.4)$ & $2(28.6)$ & 0.71 \\
\hline Is the booklet structure organized? & $5(71.4)$ & $2(28.6)$ & 0.71 \\
\hline \multicolumn{4}{|l|}{ Writing style } \\
\hline As for the understanding of the sentences, they are (Easy to understand/Difficult/Don't know) & $7(100.0)$ & $0(0.0)$ & 1.00 \\
\hline Written content is: (Clear/Confusing/Don't know) & $6(85.7)$ & $1(14.3)$ & 0.86 \\
\hline The content is: (Interesting/Uninteresting/Don't know) & $7(100.0)$ & $0(0.0)$ & 1.00 \\
\hline \multicolumn{4}{|l|}{ Appearance } \\
\hline The illustrations are: (Simple/Complicated/Don't know) & $7(100.0)$ & $0(0.0)$ & 1.00 \\
\hline Do the illustrations complement the text? & $7(100.0)$ & $0(0.0)$ & 1.00 \\
\hline Do the pages or sections appear organized? & $7(100.0)$ & $0(0.0)$ & 1.00 \\
\hline \multicolumn{4}{|l|}{ Motivation } \\
\hline In your opinion, will ostomy patients who read this booklet understand what it is about? & $7(100.0)$ & $0(0.0)$ & 1.00 \\
\hline Were you motivated to read the booklet in its entirety? & $7(100.0)$ & $0(0.0)$ & 1.00 \\
\hline Does the educational material address the necessary issues for patients with colostomy who use the plug? & $7(100.0)$ & $0(0.0)$ & 1.00 \\
\hline Did the educational booklet encourage you to act or think about using the colostomy plug? & $7(100.0)$ & $0(0.0)$ & 1.00 \\
\hline General CVI & & & 0.94 \\
\hline
\end{tabular}


The final version of the booklet entitled "Use of the colostomy plug: training and daily notes" was composed of 18 items: Presentation; Definition; Complications of the stoma and surrounding skin; For feces collection, there are several types of bags; Prevention; Continence systems; How to use the plug; How to change the plug; Frequently asked questions; Motivational tips; Reminders; Necessary guidelines; Don't forget to document everything; Write down the events; Write down your complaints; Issues and doubts; Notes diary; Where to find help. In addition, a contact list was included. This version is shown in Figure 1.

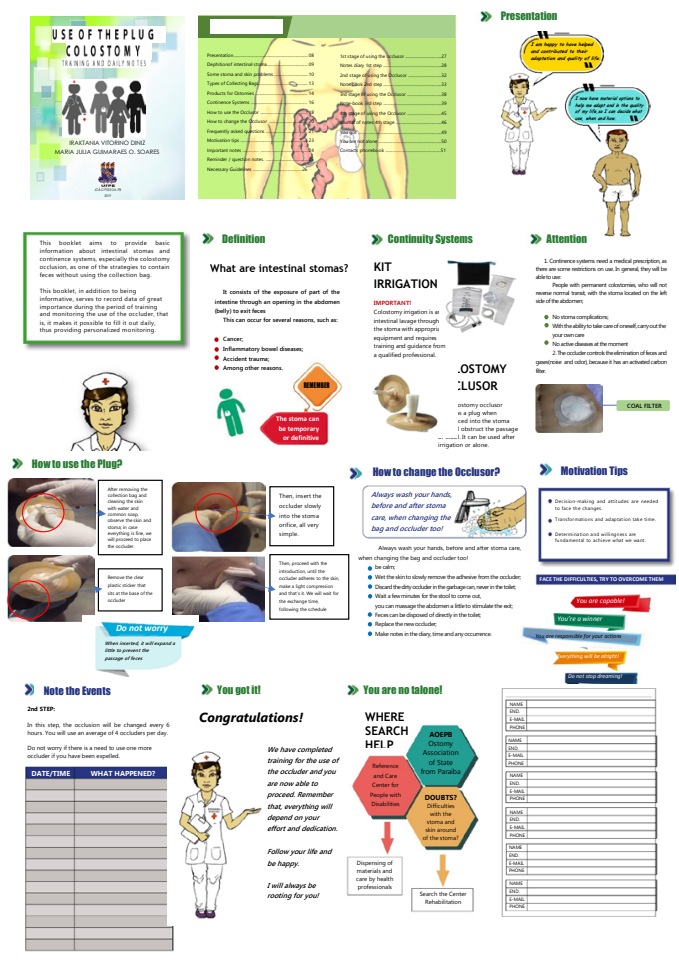

Figure 1 - Partial illustrative representation of the final version of the booklet, João Pessoa, Paraíba, Brazil, 2019

Booklet structure from left to right shown in Figure 1: Cover; Summary; Presentation (pages 8 and 9); Definition (page 10); Continence systems (page 16); Caution/plug's carbon filter (page 17); How to use the plug (pages 18 and 19); How to change the plug (page 20); Motivational tips (page 23); Write down the events (page 33); Where you able to do it? (Page 49); Where to find help; and Contact list.

After the entire validation process, the booklet was finished with 50 pages and offered to professionals in the field and to people with colostomy using the plug.

\section{DISCUSSION}

It is understood that the production of printed materials, like the booklet, provides new horizons in health promotion as it is a tangible method in which information is easily absorbed, with a direct and practical access in order to improve the capture in light of the content when compared to isolated verbal instructions. The availability of illustrative material allows for repeated approach to the reader with the information provided and facilitates the understanding of important steps for both use and adaptation to the use of the colostomy plug. Therefore, educational materials must have an interaction between the speaker, receiver, and the written content, making them an efficient pedagogical resource ${ }^{(22)}$.

The literature review was important for developing the stages of the booklet, as it indicated gaps in scientific data involving the use of the colostomy plug and mainly the educational tool aimed at teaching its use. The assumption of studies in which the importance and benefits of the plug in the lives of colostomized people were demonstrated, thus favoring adaptation to colostomy and quality of life $\mathrm{e}^{(11-14)}$, motivated us to produce the booklet.

Health education and provisioning of educational materials inform and improve self-care in ostomized individuals, with educational technology being an effective strategy to truly involve patients in their treatment, since it generates better results and, consequently, prevents complications, favoring self-care and the use of equipment. Thus, there is a need to use these scientifically validated technologies so that they can promote knowledge, assimilation, and incorporation of appropriate care to prevent complications, being adapted to the cultural and social reality of each individual ${ }^{(23)}$.

Regarding textual and visual content, the active participation of colostomized people in the production of a material ends up helping in the use of the plug as an input intended to increase their quality of life in physical, psychological, and social aspects, thus improving their appearance, self-esteem, comfort, sexuality, among others. This participation is potentially contributory to the definitive engagement of the colostomized person and, therefore, it can also help in their general well-being.

Thus, illustrative booklets with simple and direct presentation, for laypeople, positively impact learning, serving as a consultation and source of support in light of necessary doubts and questions, especially during the training phase to use a new device. Another important aspect is the possibility of accessing the booklet in printed and digital format, as a way of contemplating people regardless of their age group, education level, and access to digital technologies.

The effectiveness of learning is salutary, applying a technology such as the educational booklet, related to the integration between health actions and the training of those involved ${ }^{(24)}$.

It is noteworthy, in this context, that nursing can act both in health education interventions and in the construction and validation of educational resources. These actions must take place continuously and with diversified methodologies ${ }^{(25)}$.

\section{Study limitations}

The study limitations were the difficulty of getting the material back to the participants for their evaluation (experts and colostomized patients) in a timely manner; the cost of material for printing and diagramming; and the difficulty of online distribution due to people not having access to this resource.

\section{Contributions to the field}

The development of this booklet represents an advance in health education activities with colostomized people, as it consists of soft technology that can favor the teaching-learning process. It can be used by professionals as an auxiliary resource to train and accompany colostomized people using the plug. As an educational technology, it 
can also enhance the development of educational actions by nurses as essential activities for the empowerment and implementation of assistance to people with intestinal stoma, since the successful use of the plug favors rehabilitation, social inclusion, and self-esteem, improving the quality of life and adaptation of colostomized people.

This technology allows colostomized patients to receive basic information about intestinal stomas and continence systems, in this particular case, the plug, in addition to constituting a practical guide for self-care.

\section{CONCLUSIONS}

The booklet "Use of the colostomy plug: training and daily notes" was validated by field experts and by people with colostomies, obtaining an overall CVI greater than 0.94 . Thus, in the context of health education, the material was considered valid for use by both professionals and by people with permanent colostomy using the plug. In addition, this instrument encourages new perspectives for this population in the care process for using the plug in order to improve the quality of life and the adaptation of these people.

This educational technology focused on the use of the colostomy plug constitutes an important additional material in the process of continuous care for colostomized people and will serve as an instrument to meet the specific information needs regarding care in the use of this device.

Finally, it should be noted that the booklet is available in digital format through the following address: https://bit.ly/2RGKVVC

\section{REFERENCES}

1. Santos OJ, Sauaia FEN, Barros FAKD, Desterro VS, Teixeira SMV, Paula SPR, et al. Children and adolescents ostomized in a reference hospital. Epidemiological profile. J Coloproctol. 2016;36(2):75-9. https://doi.org/10.1016/j.jcol.2016.03.005.

2. Borges EL, Ribeiro MSR. Linha de cuidados da pessoa estomizada. Secretaria de Estado de Saúde de Minas Gerais. Belo Horizonte: SES-MG [Internet]. 2015 [cited 2020 May 28]. Available from: https://www.saude.mg.gov.br/cer/ story/8453-ses-mg-lanca-linha-de-cuidadosda-pessoa-estomizada

3. Goldberg M, Colwell J, Burns S, Carmel J, Fellows J, Hendren S, et al. WOCN Society Clinical Guideline: Management of the Adult Patient with a fecal or urinary ostomy - an executive summary. J Wound Ostomy Continence Nurs [Internet]. 2018 [cited 2020 May 23];45(1):50-8. Available from: https://www.ncbi.nlm.nih.gov/pubmed/29300288

4. Mota MS, Gomes GS, Petuco VM. Repercussions in the living process of people with stomas. Texto Contexto Enferm. 2016;25(1):1-8. https:// doi.org/10.1590/0104-070720160001260014

5. Freire DA, Angelim RCM, Souza NR, Brandão BMGM, Torres KMS, Serrano SQ. Self-image and self-care in the experience of ostomy patients: the nursing look. Rev Min Enferm. 2017;21:e-1019. https://doi.org/10.5935/1415-2762.20170029

6. Cengiz B, Bahar Z. Perceived barriers and home care needs when adapting to a fecal ostomy: a phenomenological study. J Wound Ostomy Continence Nurs [Internet]. 2017 [cited 2020 May 23];44(1):63-8. Available from: https://www.ncbi.nlm.nih.gov/pubmed/27564927

7. Coelho AR, Santos FS, Pogetto MTD. Stomas changing lives: facing the illness to survive. Rev Min Enferm. 2013;17(2):268-77. https://doi. org/10.5935/1415-2762.20130021

8. Monteiro AKC, Campos MOB, Andrade JX, Andrade EMLR. Construction and validation of an instrument for evaluation of knowledge about intestinal elimination. Enferm Foco [Internet]. 2019 [cited 2020 May 23];10(3):105-11. Available from: http://revista.cofen.gov.br/index.php/ enfermagem/article/viewFile/1890/5738

9. Lehur PA, Deguines JB, Montagliani L, Duffas JP, Bresler L, Mauvais F, et al. Innovative appliance for colostomy patients: an interventional prospective pilot study. Tec Coloproctol. 2019;23:853-9. https://doi.org/10.1007/s10151-019-02059-x

10. Santos VLCG, Cesaretti IUR. Assistência em Estomaterapia; cuidando de pessoas com estomia. 2.ed. Rio de Janeiro: Atheneu; 2015. 624p.

11. Diniz IV, Campos MGCA, Vasconcelos JMB, Martins DL, Maia FSB, Caliri MHL. Bolsa de colostomia ou sistema oclusor: vivência de colostomizados. Rev Estima [Internet]. 2013 [cited 2020 Jan 23];11(2):2, 2013. Available from: http://www.revistaestima.com.br/index.php/ estima/article/view/84

12. Airey S, Down G, Dyer S, Hulme O, Taylor I. An innovation in stoma care. Nurs Times [Internet]. 1988 [cited 2020 Jan 23];84(6):56-9. Available from: http://www.ncbi.nlm.nih.gov/pubmed/3281144

13. Cazador AC, Piñol M, Rague M, Montane J, Nogueras FM, Suñol J, et al. Estudio multicêntrico de un obturador para la continência de la colostomia. Br J Surg [Internet]. 1993 [cited 2020 Jan 23];80(7):930-2. Available from: https://bjssjournals.onlinelibrary.wiley.com/doi/ epdf/10.1002/bjs.1800800748

14. Picón PG, Calpena RR, Candela PF, Compañ RA, García GS, Meroño CE, et al. Management of colostomies with plug: clinical aspects and patient evaluation. Rev Esp Enferm Dig [Internet]. 1994 [cited 2020 Jan 23];85(2):95-8. Available from: https://www.ncbi.nlm.nih.gov/ pubmed/8186024

15. Chen F, Li ZC, Li Q, Liang FX, Guo XB, Huang ZH. A novel, intelligent, pressure-sensing colostomy plug for reducing fecal leakage. Artificial Organs. 2015;39(6):514-9. https://doi.org/10.1111/aor.12412

16. Khalilzadeh GM, Tirgari B, Roudi RO, Shahesmaeili A. Studying the effect of structured ostomy care training on quality of life and anxiety of patients with permanent ostomy. Int Wound J. 2019;16(6):1383:90. https://doi.org/10.1111/iwj.13201 
17. Salvador PTCO, Rodrigues CCFM, Lima KTN, Alves KYA, Santos VEP. Use and development of teaching technologies presented in nursing research. Rev Rene. 2015;16(3):442-50. https://doi.org/10.15253/2175-6783.2015000300018

18. Santos VC, Anjos KF, Almeida OS. A percepção de formandos sobre a pesquisa em enfermagem no curso de graduação. Rev Enferm UFSM. 2013;3(1):144-54. https://doi.org/10.5902/217976927746

19. Freitas LR, Pennafort VPS, Mendonça AEO, Pinto FJM, Aguiar LL, Studart RMB. Guidebook for renal dialysis patients: care of central venous catheters and arteriovenous fistula. Rev Bras Enferm. 2019;72(4):947-53. https://doi.org/10.1590/0034-7167-2018-0131

20. Pasquali L. Psychometrics. Rev Esc Enferm USP. 2009;43(Spe):992-9. https://doi.org/10.1590/S0080-62342009000500002

21. Coluci MZO, Alexandre NMC, Milani D. Construção de instrumentos de medida na área da saúde. Ciênc. saúde coletiva. 2015; 20(3):925-936. https://doi.org/10.1590/1413-81232015203.04332013

22. Benevides JL, Coutinho JFV, Pascoal LC, Joventino ES, Martins MC, Gubert FA, et al. Development and validation of educational technology for venous ulcer care. Rev Esc Enferm USP. 2016;50(2):306-12. https://doi.org/10.1590/S0080-623420160000200018A

23. Galdino YLS, Moreira TMM, Marques ADB, Silva FAA. Validação de cartilha sobre autocuidado com pés de pessoas com Diabetes Mellitus. Rev Bras Enferm. 2019;72(3):817-24. https://doi.org/10.1590/0034-7167-2017-0900

24. Shell DF, Newman IM, Córdova-Cazar AL, Heese JM. Driver education and teen crashes and traffic violations in the first two years of driving in a graduated licensing system. Accid Anal Prev. 2015;82:45-52. https://doi.org/10.1016/j.aap.2015.05.011

25. Viero VSF, Farias JM, Ferraz F, Simões PW, Martins JA, Ceretta LB, et al. Health education with adolescents: analysis of knowledge acquisition on health topics. Esc Anna Nery. 2015;19(3):484-90. https://doi.org/10.5935/1414-8145.20150064 